Article

\title{
Drought Impacts, Coping Responses and Adaptation in the UK Outdoor Livestock Sector: Insights to Increase Drought Resilience
}

\author{
Gloria Salmoral ${ }^{(D)}$, Benjamin Ababio and Ian P. Holman * $\mathbb{D}$ \\ Cranfield Water Science Institute, Cranfield University, Cranfield, Bedford MK43 0AL, UK; \\ Gloria.Salmoral@manchester.ac.uk (G.S.); benjaminababio46.ba@gmail.com (B.A.) \\ * Correspondence: i.holman@cranfield.ac.uk; Tel.: +44-(0)1235-750111
}

Received: 20 May 2020; Accepted: 16 June 2020; Published: 18 June 2020

check for updates

\begin{abstract}
Drought has detrimental impacts on crop and livestock farming systems worldwide, but less attention has been given to outdoor livestock systems, particularly in humid temperate regions. This research evaluated how an intense drought in 2018 impacted the UK livestock sector and the responses adopted by key actors, though a combination of analysis of weekly agricultural trade publications and semi-structured interviews with livestock farmers. Drought impacts centred on feed and fodder availability, animal productivity and welfare, farm economics, and farmer well-being, with strong inter-dependencies observed. Most drought responses by farmers were reactive short-term coping strategies to address feed shortages, with three main strategies applied: management of available grazing and feed; selling livestock to reduce feed demand and to obtain income; and buying-in additional feed. Few longer-term adaptive measures were identified due to a range of constraints. Moving forwards, the UK livestock sector needs to convert the learning from the reactive measures implemented in 2018 into pro-active drought planning approaches. The current political changes in the UK also provides a unique opportunity for agricultural policy to better reward the desirable nationally- and locally-important non-market services or public goods that livestock farming provides. Together, these should support increased drought resilience in livestock farming and increased farming viability.
\end{abstract}

Keywords: drought; livestock; responses; adaptation; coping; resilience; beef; sheep; dairy; pasture

\section{Introduction}

Agriculture is widely acknowledged as the economic sector that is most vulnerable to drought [1] with $80 \%$ of the economic losses due to drought in developing countries affecting the agriculture sector [2]. However, such large impacts are not confined to developing countries-the 2014 drought in California caused total direct losses of \$1.5 billion to the State's agricultural sector [3]. The impacts of a drought event depend on many factors including the type of drought (meteorological, agricultural, water resources), the characteristics of the drought (e.g., duration, severity, frequency); the type of farming system exposed to drought (e.g., arable, horticultural, livestock, extensive or intensive), its drought sensitivity (e.g., rain-fed or irrigated); and the adaptive capacity of the food supply chains. Much previous agricultural drought research has tended to focus on arable and horticultural cropping [4-7] due to their greater overall economic value.

There are much fewer studies on livestock systems, even though research has shown the impacts of high temperatures and drought on field-scale grass yield and quality [8]; and productivity (both quality and quantity of meat, milk, wool, etc.) and fertility in livestock, particularly cows [9,10]. This is despite drought threatening the production of livestock on the $35 \mathrm{M} \mathrm{km}^{2}$ of grass-shrub rangelands 
worldwide [11] by decreasing the production of rain-fed forage and constraining the availability of drinking water for stock. Most livestock studies have focussed on semi-arid regions due to their greater drought exposure (e.g., Arizona, USA [12]; Mexico [13]; Ethiopia [14]; Egypt [15]). Consequently, much less attention has been paid to understanding drought impacts and responses on outdoor livestock farming systems in humid temperate regions [16-18].

Although often considered a 'wet' country, the UK has experienced a number of significant annual and multi-year droughts over the past decades [19], including 1975-1976, 1983-1984, 1990-1992, 1995-1997, 2003, 2004-2006, 2010-2012 and more recently 2018 and 2019. The period May-July 2018 was the third driest for the UK (in a record from 1910), and the second driest in the east (after 1921) and north-west (after 1984) [20]. The majority of the UK registered as 'severely dry' or 'extremely dry' over this period according to the 3-month Standard Precipitation Index (Figure 1). The persistent hot, dry weather caused steep declines in river flows in responsive, largely upland, catchments, whilst dry soils and vegetation helped the spread of wildfires in northern England.

\section{SPI Areas}

Extremely dry (SPI below -2.0 )
Severely dry (SPI from -2.0 to -1.5 )
Moderately dry (SPI from -1.5 to -1.0 )
Mildly dry (SPI From -1.0 to 0.0 )
Mildly wet (SPI from 0.0 to 1.0 )
Moderately wet (SPI from 1.0 to 1.5 )
Severely wet (SPI from 1.5 to 2.0 )
Extremely wet (SPI above 2.0 )

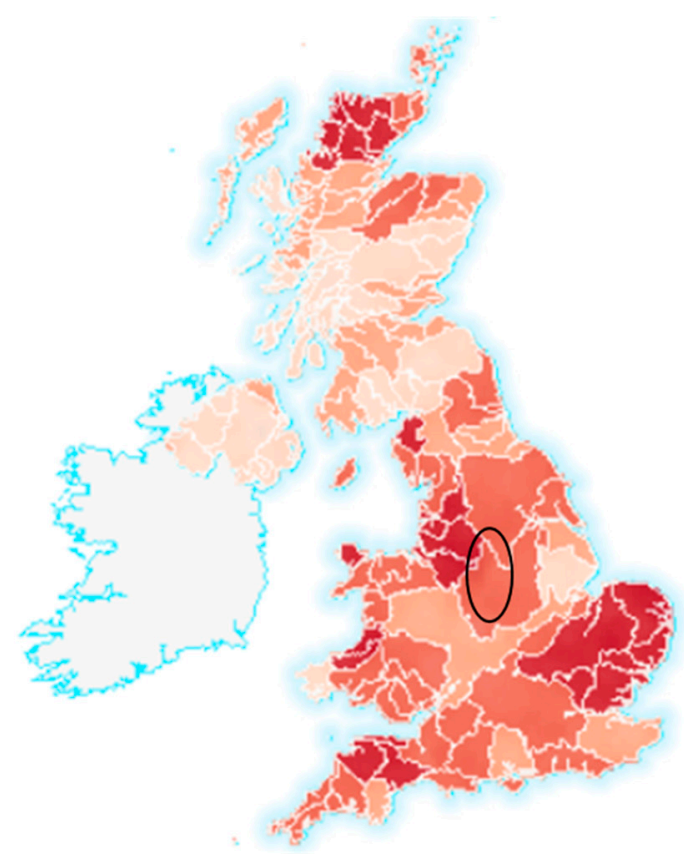

Figure 1. The 3-month Standard Precipitation Index for the UK in July 2018 (CEH Drought portal). The location of the county of Derbyshire is indicated by the black oval.

The periodic occurrence of drought in the UK has prompted various actors including farmers (producers), food industries and governmental agencies to draw lessons from previous drought events that should reduce the magnitude of drought impacts from recent and future events $[5,17]$. Wreford et al. [17] analysed annual production data of beef cattle and sheep from the early 1970s for drought event-related production deviations in drought years and the two subsequent years to allow for lags in response. They found no evidence of impacts reducing over time in both the sheep and beef sectors, suggesting little adaptation to past droughts. However, in a climate change study using a stochastic weather generator, Parsons et al. [16] used an integrated farm systems model that considered grass production, livestock feeding, animal heat balance and building conditions, to determine that future UK climatic conditions should pose no serious adaptation challenge to dairy, beef and sheep beyond increased shade provision.

This paper therefore aims to evaluate how the outdoor livestock sector in the UK was impacted by the 2018 drought, and whether the responses implemented by the different multi-level actors in the UK livestock sector show evidence for longer-term adaptation to droughts. We perform the analysis at two scales: for the UK using a text analysis of the major weekly agricultural trade magazines and an empirical case study involving semi-structured interviews with outdoor livestock farmers within the 
county of Derbyshire. The National Farmers Union (NFU) suggested Derbyshire for the case study, as it was among the livestock farming areas that were severely affected in summer 2018 (Figure 1).

\section{Materials and Methods}

This research used a mixed methods approach to evaluate the impact of, and responses to, drought on the UK livestock sector. Quantitative data from a review of reported 2018 drought impacts, responses and the associated actors in the UK livestock sector in the two main high-circulation agricultural trade magazines were combined with qualitative data from semi-structured interviews with outdoor livestock farmers in Derbyshire. The mixed methods approach provides a nuanced understanding of how livestock farmers in Derbyshire were impacted by, and responded to drought (based on the qualitative interview data), whilst permitting extrapolation (via triangulation with quantitative findings from the trade magazines) to the broader livestock sector.

\subsection{Agricultural Trade Magazine Analysis}

There are two main weekly farmer-facing agricultural trade magazines published in the UK: Farmers Weekly and Farmers Guardian, which have an average circulation per issue of $>41,000$ and $>28,000$, respectively, in 2019 [21]. Drought-related text in each issue in 2018 was extracted for further reading and coding.

Following common practice in grounded theory [22,23], the coding process of the trade magazines led to the inductive identification of impact and response themes and subthemes within the data set. Increased understanding of the dataset led to frequent checks, and re-organization of the themes and sub-themes. Classes of impacts and responses, and associated actors, were obtained based on the subject and context surrounding the exact statement or quote.

The final coded text and classifications were used to develop a conceptual framework depicting impact (sub)themes and the interactions between impact themes. The responses were then mapped onto the impacts that they aimed to reduce. Actors that were involved in providing certain form of responses were also mapped to the on-farm impacts that they indirectly addressed.

\subsection{Semi-Structured Interviews with Livestock Farmers in Derbyshire}

The classification of drought impacts and responses from the two farming periodicals provided a high-level picture of national and regional drought issues, but might miss locally-important issues. Therefore, the periodical analysis was supplemented by farmer interviews within the diverse outdoor livestock-dominated agricultural county of Derbyshire. Derbyshire is situated in the East Midlands of the United Kingdom. The county's landscape varies from upland moorlands to fertile agricultural lowlands. Livestock production is the dominant agricultural sector within the county, with around 370,000 sheep, 62,000 beef cattle and a dairy sector producing 573 million litres of milk annually worth over $£ 170 \mathrm{~m}$ [24].

A semi-structured interview template (available in the electronic Supplementary Material) was framed based on the literature review and periodical analysis and refined through two pilot interviews conducted with researchers who were knowledgeable on agricultural drought management. Approval of the questionnaire and interview protocol was obtained from the University's ethics committee. The questions assessed: (a) the nature of drought impacts experienced by the interviewees during the 2018 drought; (b) the strategies they used in coping with these impacts (c) their reasons for adopting their strategies; (d) the nature of any assistance they received during the drought; and (e) how they planned to modify their farm business to be less affected by future occurrences of drought.

Semi-structured interviews were conducted at two livestock markets in Bakewell and Leek on the 1st July, 2019 and 30th July, respectively. A total of twenty-five interviews were conducted across the two market days. The length of each interview depended on the farmer's time commitments and willingness, but most lasted between 6-10 min. Since the main aim of the interviews was to 
corroborate and enrich the national analysis, we believe that the small number of short interviews does not significantly affect the overall results.

The interviews were transcribed verbatim and the content of each interview analysed by synthesizing and classifying the data to make better inferences about the reported impacts and responses in the agricultural trade publications. Transcriptions were coded and analysed using a part-deductive part-inductive approach to thematic coding, where the researcher approached the data with a set of themes in mind from the agricultural trade publications, but remained open to the identification of new themes or sub-themes emerging from the dataset.

\section{Results}

\subsection{Impacts of the 2018 Drought}

This research presents empirical evidence as to the challenges facing the UK livestock sector during the 2018 agricultural drought in the UK. Twelve themes and sub-themes of impacts were identified in the livestock sector in the farmers magazines (Farmers Weekly and Farmers Guardian), covering grass productivity (growth and yields), feed availability, bedding availability, animal productivity (animal growth and milk production), farm economics (prices, costs and income), farmer well-being and Other. No additional impact sub-themes were identified during the interviews, although some, pertaining to grass productivity and farmer well-being had greater relative prominence in the farmer interviews. Figure 2 shows the frequency at which each sub-theme of drought impacts was reported in the farmers magazines and interviews. Concerns about feed availability and farm economics (prices and costs) were most commonly reported in the national farming magazines, whereas grass productivity (growth and yields) and costs were most commonly mentioned in the interviews, reflecting the fundamental importance of grassland to outdoor livestock farming and farmers. However, whilst almost $40 \%$ of total reports on prices were of positive impacts, only $7 \%$ of those on farm incomes were positive, reflecting the overwhelming negative impacts of the drought on farm business finances. Relative to the national farming magazines, farmer well-being was more commonly reported in the interviews reflecting the potential hidden personal burden of extreme events on farmers.

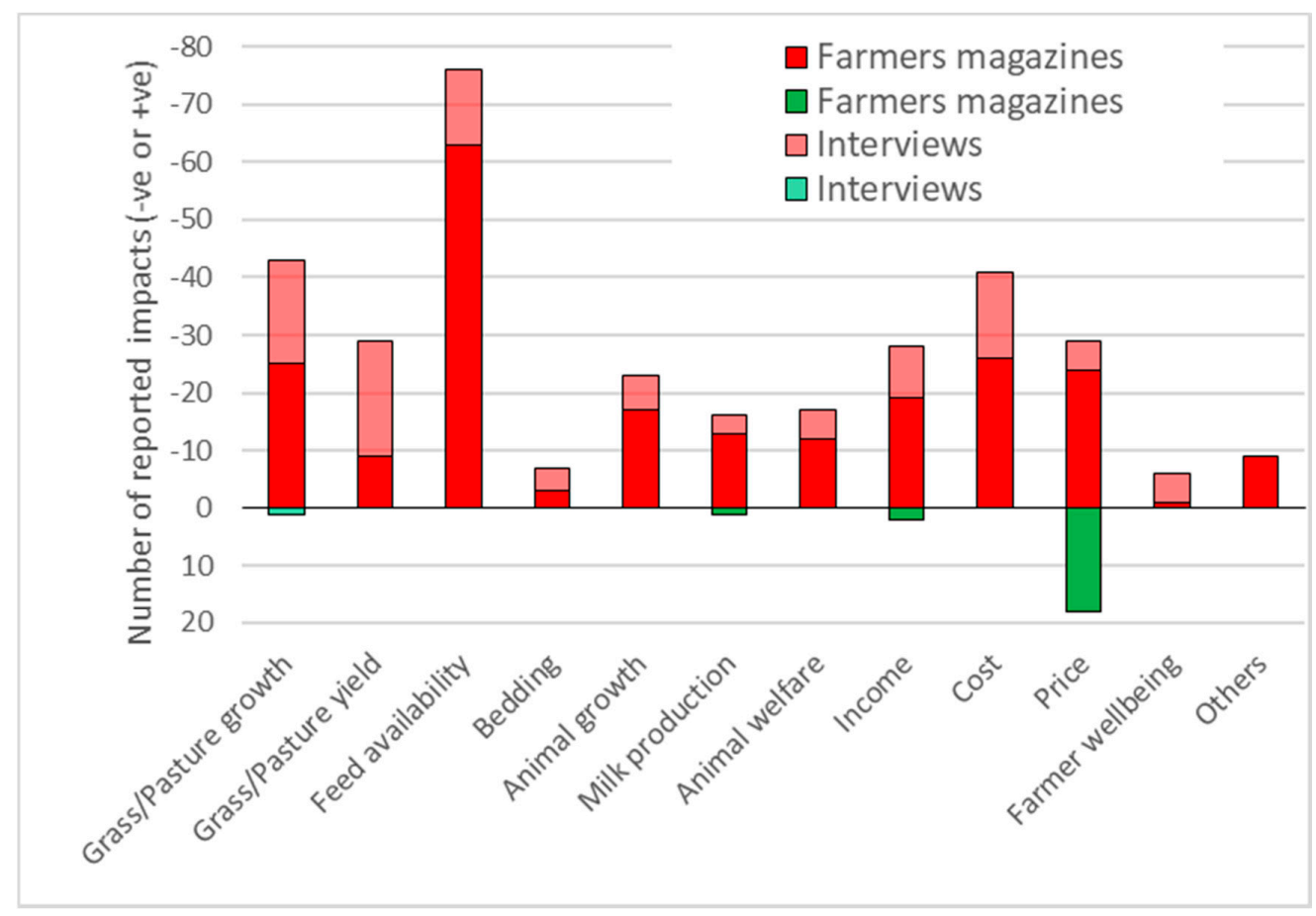

Figure 2. Reported negative (red) and positive (green) impacts of the 2018 drought on the outdoor livestock sector in UK (from farmers magazines) and Derbyshire (from interviews). 
Many of these impacts are inter-related with clear dependencies evident within the reports in the trade magazines and interviews (Figure 3 and Table 1). As an example of these inter-dependencies, the lack of rain meant that grass growth was poor, leading to reduced grass quality and hay/silage yields and an inability to sell as much hay/silage as they were planning, negatively affecting income. The lack of grass, and of reduced quality, led to potentially reduced milk production in dairy herds, poor conditions of ewes (negatively affecting lambing) and reduced growth and fertility in beef herds. It was also implicated by some interviewees as contributing to increased incidences of bovine tuberculosis.

The lack of in-field and reduced stored fodder and feed led to many farmers incurring extra costs in purchasing feed to maintain animal growth and milk production due to nationwide shortages increasing prices; selling animals leading to increased market availability and reduced prices; and early drying-off of lactating cows decreasing milk production. Only a small number of the interviewed farmers (Figure 2) experienced reduction in milk quantity, with the remaining farmers purchasing supplementary feed and concentrates to maintain milk production. The purchase of additional feed and supplements led to some interviewees reporting increases in the cost of production of $20-25 \%$, which led to some interviewees admitting that they accrued debts, in a form of credit by their suppliers, due to the constant need for feed purchases. However, those farmers with excess feed supplies benefitted from increased prices, whilst a rise in milk prices partially offset increased dairying costs.

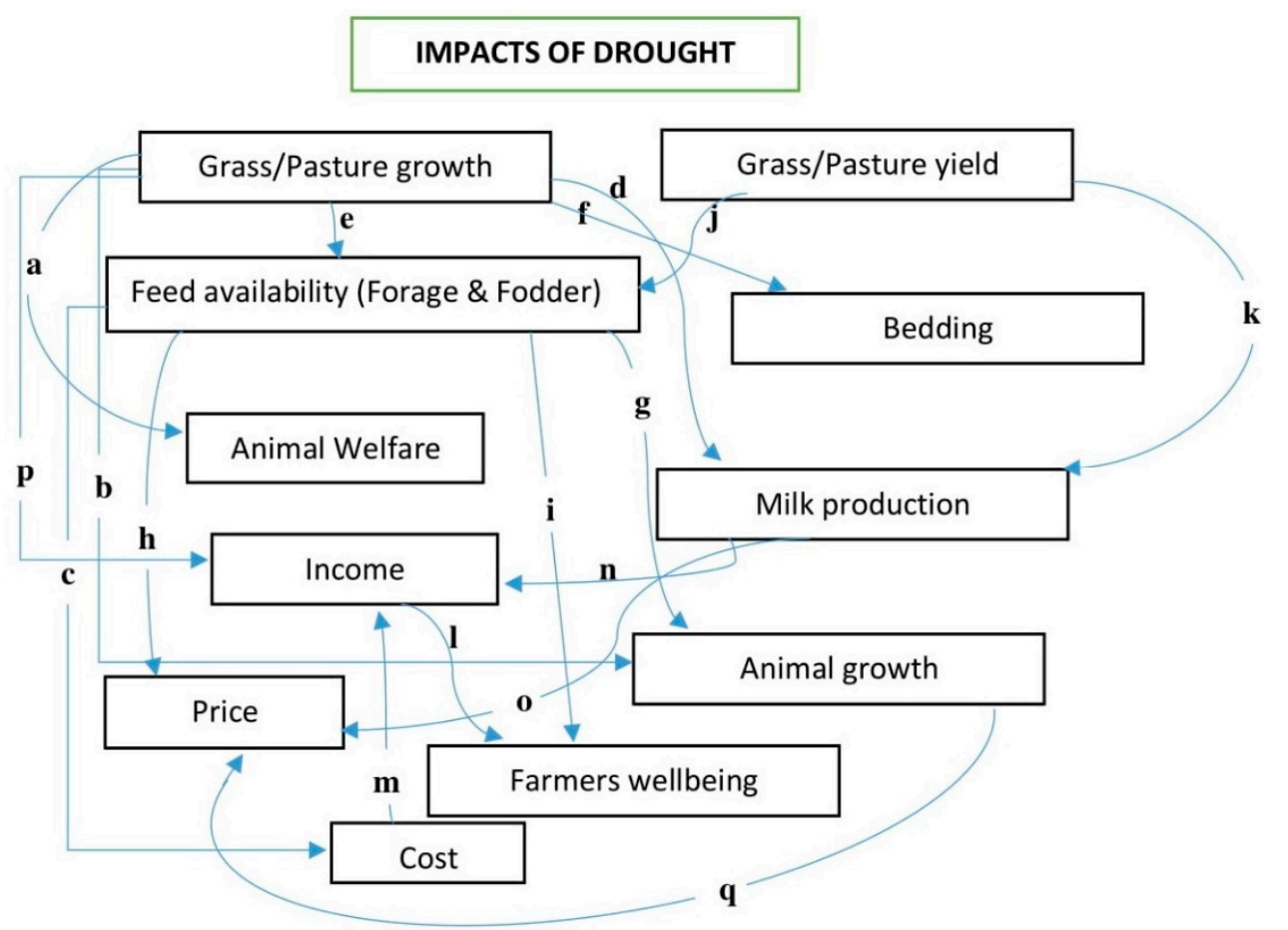

Figure 3. Schematic diagram of interdependencies among drought impacts on the livestock sector. (See Table 1 for definition and evidence supporting each link). 
Table 1. Evidence of the individual drought impacts and their resultant linkages (FW: Farmers Weekly; FG: Farmers Guardian; B: Bakewell market; L: Leek market and the number refers to the interviewee number).

\begin{tabular}{|c|c|c|}
\hline Interlinked Drought Impacts & Quotes from Agricultural Trade Publications & Quotes from Interviews \\
\hline a. Grass/Pasture growth $\Rightarrow$ Animal welfare & $\begin{array}{l}\text { It is a well-known fact there is always an elevated risk of blowfly strike in sheep } \\
\text { throughout the summer months, however the whole of the UK is currently in a } \\
\text { state of high or severe risk. (FG, July) }\end{array}$ & $\begin{array}{l}\text { I believe this [tuberculosis outbreak] was as a result of poor growth of the grass and the } \\
\text { animals were feeding on grasses very close to the soil and they were picking up the } \\
\text { pathogens from the soil" [B13] } \\
\text { We had to allow our animals to graze more at night due to hot temperatures in the day [B1] }\end{array}$ \\
\hline b. Grass/Pasture growth $\Rightarrow$ Animal growth & $\begin{array}{l}\text { "Grass is now burning up, leaving the ewes running short" (FW, July) } \\
\text { Beef and sheep farmers have also been feeling the pain of the drought, with } \\
\text { anecdotal reports of poorer fertility in beef herds and producers finding it harder } \\
\text { to finish lambs. (FW, July) }\end{array}$ & "The fertility of the animal was also affected as a result of the drought" [L9] \\
\hline $\begin{array}{l}\text { c. Feed availability (Forage \& Fodder) } \\
\qquad \Rightarrow \text { Cost }\end{array}$ & $\begin{array}{l}\text { "The NFU estimates that grass silage stocks are down by } 66 \% \text { so far this season } \\
\text { and many farmers are buying in alternative feed, which is driving up costs and } \\
\text { affecting profits" (FW, July) }\end{array}$ & $\begin{array}{l}\text { There was shortage of feed and the animals needed to be fed at all cost }[B 2] \\
\text { "The cost of purchasing feed was very high due to feed shortages and this increased cost of } \\
\text { production by almost } 20 \% \text { " [L2] } \\
\text { Since we had to purchase a lot supplement for the cows it increased our cost of production } \\
\text { by } 10 \% \text { [B6] }\end{array}$ \\
\hline d. Grass/Pasture growth $\Rightarrow$ Milk production & $\begin{array}{l}\text { "Grass quality has plummeted, causing milk to drop back a couple of litres. } \\
\text { Worryingly, we now have to graze third cut silage ground because of a lack of } \\
\text { grass growth in the absence of rain." (FW, July) }\end{array}$ & $\begin{array}{l}\text { "There were shortages of grass ... Milk production was definitely down in quantity and } \\
\text { quality I don't remember the exact figures but they went down" IL9] } \\
\text { "Our average litre of milk [production] per annum reduced by almost 10\%" [L6] }\end{array}$ \\
\hline e. Grass/Pasture growth $\Rightarrow$ Feed availability (Forage \& Fodder) & $\begin{array}{l}\text { "After a difficult winter and recent prolonged dry spell, farmers are on the verge } \\
\text { of a serious fodder crisis because of stunted grass growth" (FW, July) } \\
\text { "Our grass is looking terrible. I need } 1,200 \text { large square silage to get through the } \\
\text { winter and I've got } 650 \text { bales, with second-cut looking nonexistent" (FW, July) }\end{array}$ & $\begin{array}{l}\text { We do irrigate our grass but we couldn't irrigate enough to sustain the grass yield and the } \\
\text { only way was to buy feed [L1] }\end{array}$ \\
\hline f. Grass/Pasture growth $\Rightarrow$ Bedding & $\begin{array}{l}\text { "Livestock farmers are among those bearing the brunt of conditions. Delayed } \\
\text { drilling of spring crops means straw yields will be low and availability will be } \\
\text { tight, forcing up prices." (FW, July) } \\
\text { Drought conditions have eled to concerns of straw shortages and rising winter } \\
\text { bedding costs. Straw prices have risen } 20-50 \% \text { on the year as drought has hit } \\
\text { cereal yields. (FW, August) }\end{array}$ & \\
\hline $\begin{array}{l}\text { g. Feed availability } \\
\text { (Forage \& Fodder) } \\
\Rightarrow \text { Animal growth }\end{array}$ & $\begin{array}{l}\text { "This year's lack of grass has put lamb growth rates between 10-15\% behind } \\
\text { normal levels and that average figure masks a much more serious lack of growth } \\
\text { on some farms." (FW, July) }\end{array}$ & $\begin{array}{l}\text { Since there were shortages of feed all over the country I had to mix my straw with silage } \\
\text { and feed them to my animals [B10] }\end{array}$ \\
\hline $\begin{array}{l}\text { h. Feed availability (Forage \& Fodder) } \\
\qquad \Rightarrow \text { Price }\end{array}$ & 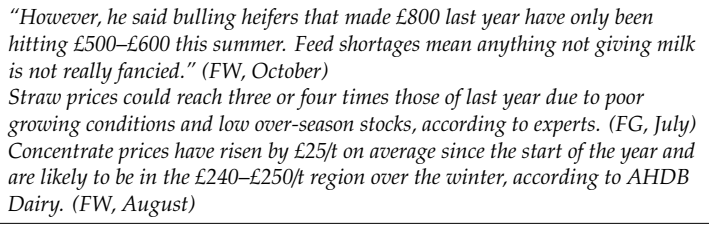 & \\
\hline $\begin{array}{l}\text { i. Feed availability (Forage \& Fodder) } \\
\Rightarrow \text { Farmers wellbeing }\end{array}$ & $\begin{array}{l}\text { "Last month we were getting more nervous by the day about the lack of } \\
\text { moisture and therefore lack of available forage for both grazing and cropping. } \\
\text { Since then, fortunately, we've had rain." (FW, August) }\end{array}$ & $\begin{array}{l}\text { "I was so stressed at that time" [B7] } \\
\text { "I was very stressed during this time of production" [L2] }\end{array}$ \\
\hline $\begin{array}{l}\text { j. Grass/Pasture yield } \\
\Rightarrow \text { Feed availability (Forage \& Fodder) }\end{array}$ & $\begin{array}{l}\text { "However, yields are down and the straw is minimal. Everyone is desperate for } \\
\text { straw this year." }\end{array}$ & $\begin{array}{l}\text { "There were shortages of grass and not only were we short of feed for last year (2018) but } \\
\text { we were short of winter feed for the spring this year (2019) as well" [L9] }\end{array}$ \\
\hline
\end{tabular}


Table 1. Cont.

\begin{tabular}{|c|c|c|}
\hline Interlinked Drought Impacts & Quotes from Agricultural Trade Publications & Quotes from Interviews \\
\hline $\begin{array}{l}\text { k. Grass/Pasture yield } \\
\Rightarrow \text { Milk production }\end{array}$ & $\begin{array}{l}\text { "Grass quality has plummeted, causing milk to drop back a couple of litres. } \\
\text { Worryingly, we now have to graze third cut silage ground because of a lack of } \\
\text { grass growth in the absence of rain." (FW, July) } \\
\text { "The processor warns that dry weather is starting to affect milk production, and } \\
\text { that it has the potential to seriously affect milk supplies over the next few } \\
\text { months." (FW, July) }\end{array}$ & $\begin{array}{l}\text { "Milk production was definitely down in quantity and quality I don't remember the exact } \\
\text { figures but they went down" [L9] }\end{array}$ \\
\hline 1. Income $\Rightarrow$ Farmer wellbeing & $\begin{array}{l}\text { "The practical worries and financial concerns have undoubtedly taken their toll. } \\
\text { But one thing that has helped him deal with the stress has been a WhatsApp } \\
\text { group set up with other farmers from Twitter. "We can share ideas, have a rant } \\
\text { on a bad day - it does help. And once I had made those difficult decisions, I felt } \\
\text { so much better." (FW, August) }\end{array}$ & "I was so depressed since my business was not moving as expected" [B12] \\
\hline $\mathrm{m}$. Cost $\Rightarrow$ Income & $\begin{array}{l}\text { "The NFU estimates that grass silage stocks are down by } 66 \% \text { so far this season } \\
\text { and many farmers are buying in alternative feed, which is driving up costs and } \\
\text { affecting profits." (FW, July) }\end{array}$ & $\begin{array}{l}\text { "The only issue we had was issues with cash flow because we had to be purchasing } \\
\text { additional feed for our animals and that affected our income" [L1] }\end{array}$ \\
\hline $\begin{array}{l}\text { n. Milk production } \\
\Rightarrow \text { Income }\end{array}$ & $\begin{array}{l}\text { "Mr Lucas said: "I'd say farmers were confident in the medium-term milk price. } \\
\text { But there could be a scenario where people have to buy more feed again. Milk is } \\
\text { dropping and farms will be looking to keep production level." (FW, July) }\end{array}$ & $\begin{array}{l}\text { "Milk production was not affected to a great extent and both the quantity and quality was } \\
\text { averaging the same at the previous years but we had to incur extra cost of purchasing } \\
\text { supplement in order to achieve that" [L2] } \\
\text { "Any animal that was not productive at this time of production was culled" [L2] }\end{array}$ \\
\hline $\begin{array}{l}\text { o. Milk production } \\
\quad \Rightarrow \text { Price }\end{array}$ & $\begin{array}{l}\text { "He added that with UK cheese stocks already low, reduced production would } \\
\text { push consumer prices up and could potentially lead to a cheese shortage in the } \\
\text { spring." (FW, August) }\end{array}$ & $\begin{array}{l}\text { "Milk prices last summer was high so we also had reasonable income as a result of } \\
\text { that" [B9] }\end{array}$ \\
\hline p. Grass/Pasture growth $\Rightarrow$ Income & $\begin{array}{l}\text { "Straw prices continue to climb amid growing concern that high temperatures } \\
\text { and lack of rain this summer will result in severe forage and bedding shortages } \\
\text { this winter." (FW August) }\end{array}$ & $\begin{array}{l}\text { "We sold some of our animals to reduce our stock because of the drought" [L3] } \\
\text { We couldn't sell feed at this time and all the feed we grew on the farm were used to feed } \\
\text { our own animals [B1] } \\
\text { "We sell feed to other farmers but we couldn't harvest enough to sell and this affected our } \\
\text { income" [L4] }\end{array}$ \\
\hline $\begin{array}{l}\text { q. Animal growth } \\
\Rightarrow \text { Price }\end{array}$ & $\begin{array}{l}\text { "Grazing concerns and a drop in ewe condition were the main drought-related } \\
\text { factors restraining prices at Thame last week (2-3 August) as 25,821 sheep } \\
\text { went under the hammer" (FW August) }\end{array}$ & \\
\hline
\end{tabular}




\subsection{Responses to the 2018 Drought}

Thirteen classes of response in the livestock sector were identified from the agricultural trade magazines (Figure 4), which were separated into shorter-term (or within-drought) coping mechanisms and longer term (strategic) adaptive responses.

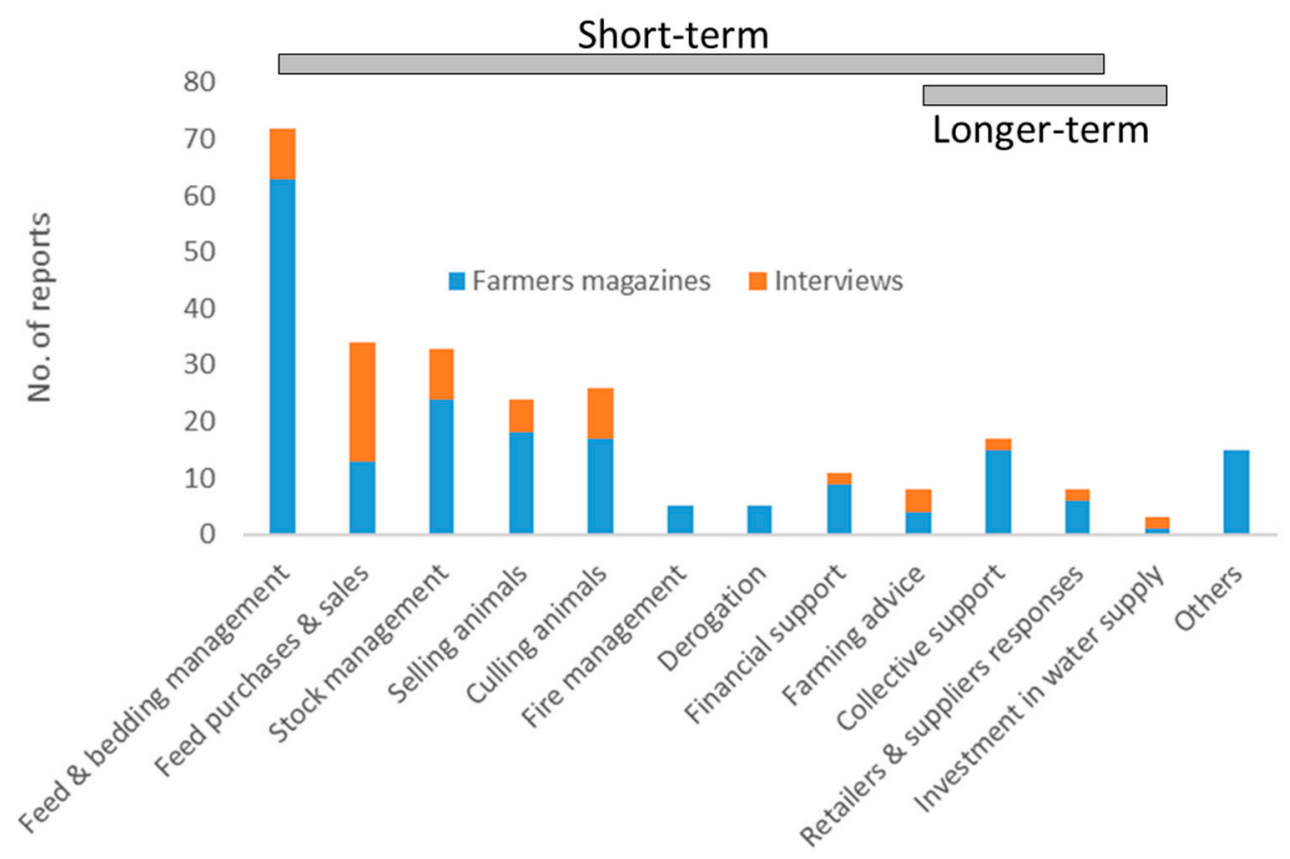

Figure 4. Responses to the impacts of 2018 drought on UK's livestock sector reported in national farmers magazines (UK) and interviews (Derbyshire).

\subsubsection{Short-term Responses}

Given the reported impacts on grass productivity and feed and bedding availability, it is unsurprising that feed and bedding management were the most commonly reported response in 2018 . Feed management practices included forage budgeting, limited allocation or buffer feed, feeding first cut-silage, use of winter feed supplies, feeding concentrates as a substitute for forage, and feeding ewes with supplements after weaning lambs. Feed purchases were also commonly reported, particularly in the farmer interviews where the majority ( 21 out of 25 ) of the livestock farmers purchased additional feed, whilst nine used their stored winter feed (winter barley and wheat) supplies. Arable farmers at the time of the drought were reported to have baled as much straw to sell to livestock farmers to address issues of supply deficit.

Fire precautions were also encouraged and implemented during harvest due to the very dry field conditions. Examples of fire management responses reported included ensuring harvesting machinery was chaff-free; having a tractor ready to cut a fire break if necessary; keeping a full water tank nearby; having fire extinguishers; and removing hay and straw from fields as soon as possible.

Stock management practices such as drying cows early, grazing at night, and managing weight control, were also reported in the trade magazines and interviews. However, many farmers, including nine of the interviewees, also responded by selling animals, particularly barren cows, spare youngstock and poorer milkers, to reduce the feed burden and generate funds to purchase feed to maintain their breeding herd. When asked during the interviews as to the underlying rationale for adopting particular coping mechanisms, responses varied from a need to provide their animals with feed no matter the constraints; that their responses were simply their experiential indigenous knowledge in tackling situations of this nature and not based on an explicit drought responses, and the importance of maintaining desirable traits (such as milk quality, healthy progeny, fertility) within the breeding herd: 
"We didn't sell our animals because we needed the parents with good quality traits to be around during subsequent production cycles" [L6]

Not all drought responses were initiated on-farm, with a range of top-down actions being implemented by the industry, government and retailers (Figure 5). A number of examples of collective action were reported, including national farmers groups and industry levy boards providing livestock farmers with drought advice and helplines; the National Farmers Union relaunched its Fodder Bank scheme to help members access bedding and straw; and charity organisations, such as the Royal Agricultural Benevolent Institution (RABI) and Forage Aid, provided livestock farmers with emergency grants, and access to straw and bedding, respectively.

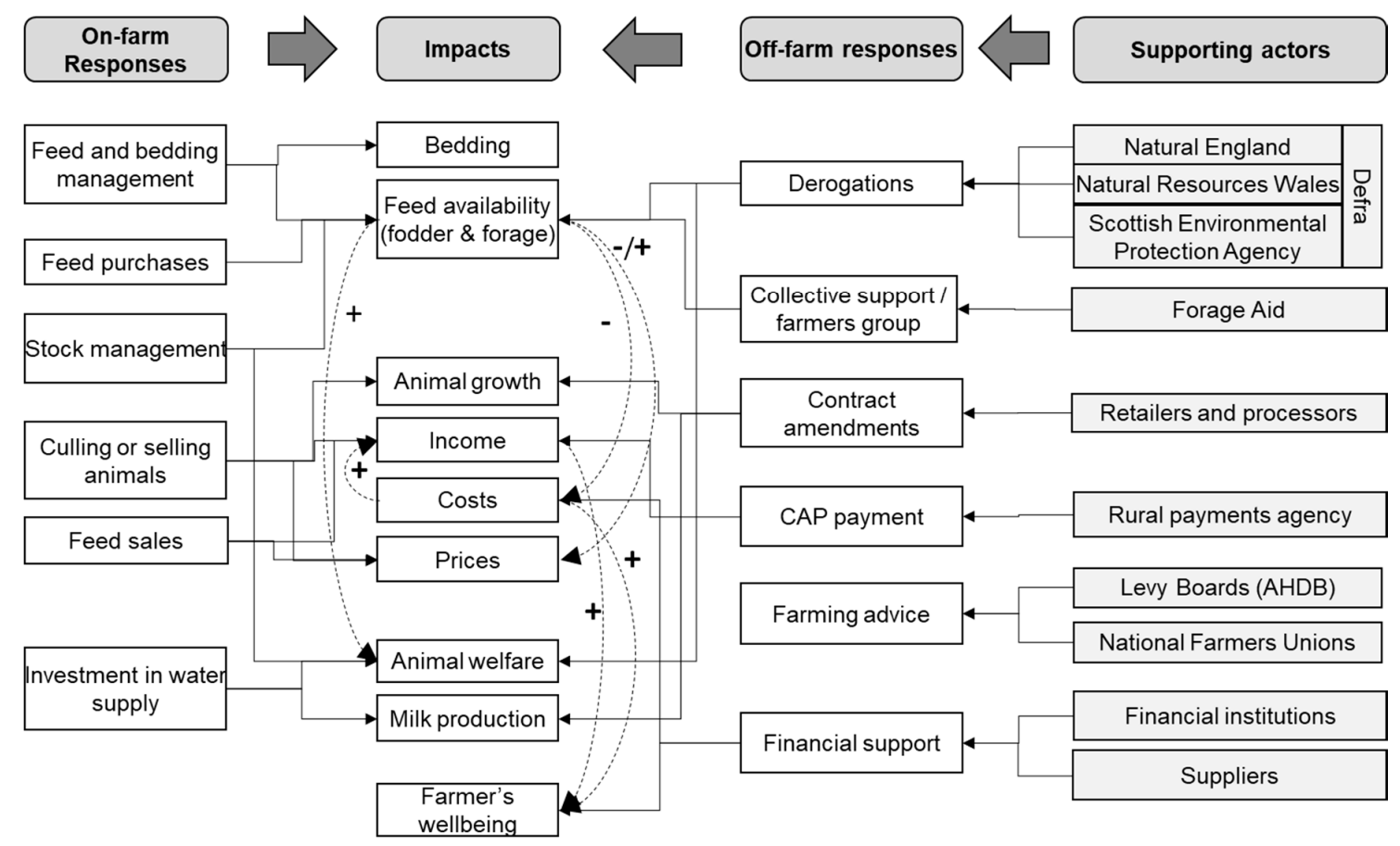

Figure 5. Conceptual model outlining how on-farm responses and off-farm supporting responses by multi-level key actors addressed the impacts of 2018 drought on livestock sector. The dashed lines (and "+", "_") indicate how these responses positively or negatively affected key impacts.

Government derogations relaxed certain regulations on farming activity. For example, 40 temporary prescription adjustments (TPA) to stewardship scheme constraints on grazing and grass cutting were announced to assist farmers with extra fodder and bedding. One of the interviewees within an environmental scheme benefitted from this permission to cut his grass early due to the feed shortages. Positive examples of private sector responses were reported, including flexible loan agreements between livestock farmers and financial institutions; retailers' and processors' modifications to the contractual terms and specifications of livestock products were reported as well.

\subsubsection{Longer-term Responses}

Whilst some of the aforementioned short-term responses (such as provision of advice, collective action and contractual modifications) might also engender some longer term benefits, there were few explicitly adaptive measures that increase the resilience of livestock farms to impacts of drought reported in the Farmers Weekly and Farmers Guardian. Most related to increasing water supply availability, ranging from connecting to on-farm hydroelectric water pipes to purchasing lakes as a method of safeguarding against future drought; being pro-active in ensuring early hay stocks as a defensive mechanism to provide a guaranteed feed supply to farms; and stock management practices that enable farmers to raise animals on outdoor pastures. This limited consideration of longer-term 
drought resilience was mirrored in the interviews where $68 \%$ of the interviewees admitted to not having any adaptive measures to secure their farms against future drought events. Examples provided in the interviews included construction of boreholes, maintaining a sizeable herd, and having spare fields established with grass to safeguard against future hay and silage shortages:

I had an extra field set aside for grazing. I established this field in anticipation of challenges that may result in feed shortages [B5]

\subsection{Linking Responses to Impacts: A Conceptual Model}

Using the impact and responses themes and insights, Figure 5 synthesises the livestock farming systems' response to the impacts of the 2018 drought. The impact dependencies within Figure 1 means that the implemented responses in Figure 5 can reduce impacts directly (e.g., collective support will help to increase feed availability) and also lead to indirect benefits (e.g., decreased farmers' costs and improved wellbeing). Most of the farmer-centred responses were directed towards directly and indirectly resolving the linked challenges of feed availability, animal welfare and productivity and managing finances. The supporting responses of external actors synergistically helped to reduce the overall impacts on individual businesses and the sector. For example, the multiple responses of farmers and supporting actors to increase feed availability reduce additional feed costs, thereby supporting a relative improvement in farm incomes and farmer well-being. For some farmers, those actions to increase feed availability might lead to reduced prices for feed that they planned to sell. Understanding these inter-dependencies and the systemic cascade of direct and indirect benefits of responses is important in designing effective drought response strategies.

\section{Discussion}

This research characterised the diverse impacts of the 2018 drought on the UK outdoor livestock sector and evaluated to what extent the responses implemented by various actors assisted the sector in becoming more resilient to the inevitable future drought events and climate change [25]. Given the climatic, topographical and agronomic diversity of the UK, drought management practices in the outdoor livestock sector might be expected to vary regionally [17]. However, our national and local results for the 2018 drought have shown strong similarities in the reported drought responses of the UK livestock farmers, that have generally focussed on short-term coping mechanisms. The significant and extensive impacts across the country, despite multiple past droughts, provide little evidence of the progressive development of increased agricultural drought resilience as postulated by [17].

Unsurprisingly, the major challenge with drought faced by the outdoor livestock sector relates to feed supply [26]. The main short-term strategies identified in 2018 centred around managing feed availability, with three main strategies applied: management of available grazing and feed; selling livestock to reduce feed demand and to obtain income [27]; and buying-in additional feed to meet demand. These measures are consistent with those reported in the livestock sector elsewhere in the world $[12,18]$ where most livestock farmers modify feed management practices as their principal drought coping strategies [28]. This shows a largely common approach to the management of drought risk that is reactive and crisis-driven [29], with potentially negative consequences for health and social outcomes [30]. Additional drought actions such as early weaning, due to the higher nutritional feed demand of lactating animals [31] and enhanced subsequent rate of conception during drought [32], are considered "no regret" practices by [29].

Our study showed a general lack of longer-term drought resilience strategies, with most of the interviewees not having any explicit long-term strategies. An implicit longer-term resilience strategy (though not necessarily for drought resilience) was the strong emphasis of many farmers (also reported in the trade magazines) on maintaining desired long-term genetic quality attributes within their herd (fertility, milk quality, healthy progeny; tolerance to harsh environmental conditions, etc.) through selective selling or culling [33]. Farmers' decisions about selecting and implementing long-term strategies are informed by multiple factors including, amongst many, practicality [34], perceptions of 
changes to the climate and how relevant or permanent those changes would be [17], and available incentives and advice [34,35]. However, in their review of factors influencing farmers' adoption of best management practices, [35] found no studies that reported climate change and extreme weather events to be a significant factor. In our study, the main long-term strategy was to secure water supplies, despite feed availability being the main drought impact. What explains this apparent contradiction?

Firstly, there is a lack of top-down support for a transition away from ad hoc reactive measures to longer term anticipatory drought management planning. Such a proactive approach needs to be supported by a range of appropriate activities, including drought monitoring and early warning systems capable of delivering useful and timely information for multiple levels of decision-making [36] from farms to businesses to national strategy; effective tools and procedures for assessing impacts, proactive planning in advance of droughts, and emergency response programs [37]. Pro-active drought risk management is well supported in the irrigated agricultural sector [5] by regulatory water resources drought management plans [38], monitoring and forecasting systems [39,40] and drought risk management tools [41]. In contrast, the focus of much effort by government, research and retailers has been on reducing the environmental burdens of livestock production (e.g., water quality [42,43]; greenhouse gas emissions [34,44]) rather than reducing the environment's impact on livestock agriculture.

The likelihood of farmers adopting long-term measures is influenced by many socio-economic factors including the farmer's age and education level [35], access to information [45], farmer's experience [46,47] and presence of a successor [48]. Similarly to in many countries, the UK agriculture sector has a progressively aging workforce, with around a third of all UK farm holders over the typical retirement age of 65 years, while the proportion of young people aged less than 35 years is around $3 \%$ [49]. Hence the lack of succession in many small farms can act as a barrier to longer-term decision making [50].

Having reserve pastures [12] and extending and over-sizing the pasture areas in relation to the needs of the herd [18] have been identified as important drought resilience measures in other countries. However, in a densely populated and agriculturally-managed country where land is largely privately-owned as in the UK, there are fewer opportunities to expand farm area, either due to lack of available land or challenges in financing farm expansion that does not involve increased production. Consequently, opportunities for increasing long-term drought resilience are limited.

Intensification of feed production (through increased nitrogen application; conversion from grassland to ley-arable systems, etc.) and extensification (with fewer stock per hectare) both have drawbacks. Opportunities for intensification are limited by soil, topographical and climate constraints in upland environments [18] and are increasingly inconsistent with environmental (e.g., cross-compliance in the Common Agricultural policy) and water quality (e.g., the European Water Framework Directive) priorities in both upland and lowland environments. Given that droughts are an extreme event, extensification means a reduction in income in most wet and normal years (unless accompanied by a quality-based price premium [51]), which may only be partially offset by a relative increase in income in the occasional dry years.

Livestock systems in humid temperate regions, particularly in upland areas, therefore operate in a challenging environment which restricts intensification strategies, and where they are particularly exposed to drought risks because of their largely grass-based system [18]. Moving forwards, we identify two critical transitions for supporting increased drought resilience in the UK livestock sector. Firstly, there should be deliberate efforts to convert the learning from the implementation of reactive measures in 2018 into pro-active drought planning. This is needed to facilitate rapid and flexible information and support for farmers to enable them to react to often rapidly changing farming conditions [45]. This shift away from reactive responses is needed at all levels [5], from improved on-farm fodder management and budgeting systems; to retailer contract amendments that rapidly facilitate temporary relaxation of assurance standards; to temporary derogations of environmental stewardship requirements under clearly defined circumstances. 
Secondly, whilst extensification can provide improved drought resilience, promoting such approaches requires dedicated policies or incentives to help farmers overcome barriers to uptake, particularly when measures are unprofitable [52]. In the UK, Brexit and the new UK Agriculture Bill [53] provides such an opportunity [54], with post-Common Agricultural Policy (CAP) agricultural support [55] moving away from area-based payments towards Payment for Public Goods [56]/Payment for Ecosystem Services [57]. These approaches recognise that agricultural systems provide many desirable non-market services or public goods to society [51,58] which require public support [56]. Such payments may support enhancements of critical public goods, such as carbon sequestration, flood regulation, cultural services, recreation, etc. There is thus the potential opportunity for future rural land policy to deliver a major win-win that benefits the farming community, tax payers and wider society and the environment: enhanced delivery of nationally- and locally-important public goods, increased drought resilience in livestock farming and increased outdoor livestock farming viability.

\section{Conclusions}

Outdoor livestock farms, particularly but not exclusively in upland areas, are naturally sensitive to drought because of their reliance on grass production for grazing and stored feed (hay, silage). The 2018 drought in the UK had significant impacts on grass growth, leading to complex inter-linked impacts on feed availability, prices, farm incomes and farmer and animal welfare. A review of weekly agricultural trade magazines and farmer interviews showed a range of short-term coping responses, focused on management of available grazing and feed; selling livestock to reduce feed demand and to obtain income; and buying-in additional feed to meet demand. The lack of top-down support for a transition away from ad hoc reactive measures to longer term anticipatory drought management planning, compounded by limited opportunities for both intensification and extensification, provides little evidence of increased drought resilience. However, the departure of the United Kingdom from the European Union and the new UK Agriculture Bill provides an important opportunity to focus public funding to agriculture on the public goods that livestock farming can deliver, leading to enhanced drought resilience.

Supplementary Materials: The following are available online at http://www.mdpi.com/2073-445X/9/6/202/s1.

Author Contributions: Conceptualization, G.S., I.P.H., B.A.; Methodology, G.S., I.P.H., B.A.; Formal Analysis, B.A.; Investigation, B.A.; Data Curation, G.S.; Writing-Original Draft Preparation, I.P.H.; Writing-Review \& Editing, G.S. and I.P.H.; Visualization, B.A. and I.P.H.; Supervision, G.S. and I.P.H.; Project Administration, G.S.; Funding Acquisition, I.P.H. All authors have read and agreed to the published version of the manuscript.

Funding: This research was funded by the UK Droughts \& Water Scarcity (D\&WS) programme, a Natural Environment Research Council programme in collaboration with other UK Research Councils (Economic and Social Research Council, Engineering and Physical Sciences Research Council, Biotechnology and Biological Sciences Research Council and Arts and Humanities Research Council), grant number NE/L010070/1.

Acknowledgments: We would like to give special thanks to Andrew Critchlow and Paul Hammett of the National Farmers Union for their support and to the farmers at Bakewell and Leek market for their participation. The historic droughts inventory of references from agricultural media is freely available from http://reshare.ukdataservice.ac. $\mathrm{uk} / 853167 /$.

Conflicts of Interest: The authors declare no conflict of interest.

\section{References}

1. Wilhite, D. Preparedness and coping strategies for agricultural drought risk management: Recent progress and trends. In Managing Weather and Climate Risks in Agriculture; Sivakumar, M.V.K., Motha, R.P., Eds.; Springer: New York, NY, USA, 2007; pp. 21-38.

2. FAO. Droughts and Agriculture; Food and Agriculture Organization: Rome, Italy, 2017; Available online: http://www.fao.org/3/a-i7378e.pdf (accessed on 1 May 2020). 
3. Howitt, R.E.; Medellin-Azuara, J.; MacEwan, D.; Lund, J.R.; Sumner, D.A. Economic Analysis of the 2014 Drought for California Agriculture; Center for Watershed Sciences, University of California: Davis, CA, USA, 2014; p. 20. Available online: https://watershed.ucdavis.edu/files/biblio/DroughtReport_23July2014_0.pdf (accessed on 1 May 2020).

4. Fahad, S.; Bajwa, A.A.; Nazir, U.; Anjum, S.A.; Farooq, A.; Zohaib, A.; Sadia, S.; Nasim, W.; Adkins, S.; Saud, S.; et al. Crop Production under Drought and Heat Stress: Plant Responses and Management Options. Front. Plant Sci. 2017, 8, 1147. [CrossRef] [PubMed]

5. Rey, D.; Holman, I.; Knox, J.W. Developing drought resilience in irrigated agriculture in the face of increasing water scarcity. Reg. Environ. Chang. 2017, 17, 1527-1540. [CrossRef] [PubMed]

6. Bodner, G.; Nakhforoosh, A.; Kaul, H.-P. Management of crop water under drought: A review. Agron. Sustain. Dev. 2015, 35, 401-442. [CrossRef]

7. Parry, M.A.J.; Flexas, J.; Medrano, H. Prospects for crop production under drought: Research priorities and future directions. Ann. Appl. Biol. 2005, 147, 211-226. [CrossRef]

8. Sheaffer, C.C.; Peterson, P.R.; Hall, M.H.; Stordahl, J.B. Drought Effects on Yield and Quality of Perennial Grasses in the North Central United States. J. Prod. Agric. 1992, 5, 556-561. [CrossRef]

9. De Rensis, F.; Scaramuzzi, R.J. Heat stress and seasonal effects on reproduction in the dairy cow-A review. Theriogenology 2003, 60, 1139-1151. [CrossRef]

10. Alves, M.F.; Gonçalves, R.; Pavão, D.L.; Palazzi, E.G.; Souza, F.; De Queiróz, R.K.R.; Angelo, M.D.; De Achilles, M.A. Effect of heat stress on the maturation, fertilization and development rates of in vitro produced bovine embryos. Open J. Anim. Sci. 2013, 3, 174-178. [CrossRef]

11. Safriel, U.; Adeel, Z.; Niemeijer, D.; Puigdefabregas, J.; White, R.; Lal, R.; Winslow, M.; Ziedler, J.; Prince, S.; Archer, E.; et al. Dryland systems. In Ecosystems and Human Wellbeing: Current State and Trends: Findings of the Condition and Trends Group; Hassan, R., Scholes, R., Ash, N., Eds.; Island Press: Covelo, CA, USA, 2005; pp. 346-623.

12. McClaran, M.P.; Butler, G.J.; Wei, H.; Ruyle, G.D. Increased preparation for drought among livestock producers reliant on rain-fed forage. Nat. Hazards 2015, 79, 151-170. [CrossRef]

13. Murray-Tortarolo, G.N.; Jaramillo, V.J. The impact of extreme weather events on livestock populations: The case of the 2011 drought in Mexico. Clim. Chang. 2019, 153, 79-89. [CrossRef]

14. Catley, A.; Admassu, B.; Bekele, G.; Abebe, D. Livestock mortality in pastoralist herds in Ethiopia and implications for drought response. Disasters 2014, 38, 500-516. [CrossRef]

15. Alary, V.; Messad, S.; Aboul-Naga, A.; Osman, M.; Daoud, I.; Bonnet, P.; Juanes, X.; Tourrand, J. Livelihood strategies and the role of livestock in the processes of adaptation to drought in the Coastal Zone of Western Desert (Egypt). Agric. Syst. 2014, 128, 44-54. [CrossRef]

16. Parsons, D.J.; Armstrong, A.C.; Turnpenny, J.; Matthews, A.J.; Cooper, K.; Clark, J.A. Integrated models of livestock systems for climate change studies. 1. Grazing systems. Glob. Chang. Biol. 2001, 7, 93-112. [CrossRef]

17. Wreford, A.; Adger, W.N. Adaptation in agriculture: Historic effects of heat waves and droughts on UK agriculture. Int. J. Agric. Sustain. 2010, 8, 278-289. [CrossRef]

18. Nettier, B.; Dobremez, L.; Coussy, J.-L.; Romagny, T. Attitudes of livestock farmers and sensitivity of livestock farming systems to drought conditions in the French Alps. Rev. Geogr. Alp. J. Alp. Res. 2011, 98, 383-400. [CrossRef]

19. Marsh, T.; Cole, G.; Wilby, R. Major droughts in England and Wales, 1800-2006. Weather 2007, 62, 87-93. [CrossRef]

20. Centre for Ecology and Hydrology. UK Hydrological Status Update-Early August 2018. 2018. Available online: https://www.ceh.ac.uk/news-and-media/blogs/uk-hydrological-status-update-early-august-2018 (accessed on 6 April 2020).

21. ABC. Audited Circulation Certificates. 2020. Available online: https://www.abc.org.uk/Certificates/49664504. pdf and https://www.abc.org.uk/Certificates/49664449.pdf (accessed on 1 May 2020).

22. Bryant, A. The Grounded Theory Method. In The Oxford Handbook of Qualitative Research; Leavy, P., Ed.; Oxford University Press: Oxford, UK, 2014; pp. 115-136.

23. Patton, M.Q. Qualitative Evolution and Research Methods, 2nd ed.; Sage: Newbury Park, CA, USA, 1990; pp. 169-186. 
24. National Farmers Union. What Farming Delivers for Derbyshire. 2013. Available online: https://www. nfuonline.com/farming-delivers-for-derbyshire-leaflet/ (accessed on 15 June 2020).

25. Hopkins, A.; Del Prado, A. Implications of climate change for grassland in Europe: Impacts, adaptations and mitigation options: A review. Grass Forage Sci. 2007, 62, 118-126. [CrossRef]

26. Wheeler, T.; Reynolds, C. Predicting the risks from climate change to forage and crop production for animal feed. Anim. Front. 2013, 3, 36-41. [CrossRef]

27. Morton, J.; Barton, D. Destocking as a drought-mitigation strategy: Clarifying rationales and answering critiques. Disasters 2002, 26, 213-228. [CrossRef]

28. Zhang, Y.W.; McCarl, B.A.; Jones, J. An Overview of Mitigation and Adaptation Needs and Strategies for the Livestock Sector. Climate 2017, 5, 95. [CrossRef]

29. Cruz, G.; Baethgen, W.; Bartaburu, D.; Bidegain, M.; Giménez, A.; Methol, M.; Morales, H.; Picasso, V.D.; Podestá, G.; Taddei, R.R.; et al. Thirty Years of Multilevel Processes for Adaptation of Livestock Production to Droughts in Uruguay. Weather Clim. Soc. 2018, 10, 59-74. [CrossRef]

30. Edwards, B.; Gray, M.; Hunter, B.H. The social and economic impacts of drought. Aust. J. Soc. Issues 2018, 54, 22-31. [CrossRef]

31. Doran, M. Managing Livestock during Drought: Destocking and Early Weaning. 2014. Available online: http://ucanr.edu/sites/placernevadasmallfarms/files/181318.pdf (accessed on 1 May 2020).

32. Beck, P.; Borengasser, M.; Bryant, K.; Gadberry, S.; Jennings, J.; Jone, S.; Loftin, K.; Popp, M.; Powell, J.; Montgomery, G.; et al. Drought Management and Recovery for Livestock Systems; University of Arkansas Cooperative Extension Service: Little Rock, AR, USA, 2014; pp. 1-69.

33. Gill, R.; Pinchak, B. Destocking Strategies during Drought; Texas Cooperative Extension: University City, TX, USA, 1999; Available online: http://varietytesting.tamu.edu/files/forages/drought/Destocking\%20Strategies\% 20During\%20Drought.pdf (accessed on 1 May 2020).

34. Jones, A.; Jones, D.L.; Edwards-Jones, G.; Cross, P. Informing decision making in agricultural greenhouse gas mitigation policy: A Best-Worst Scaling survey of expert and farmer opinion in the sheep industry. Environ. Sci. Policy 2013, 29, 46-56. [CrossRef]

35. Liu, T.; Bruins, R.J.F.; Heberling, M.T. Factors Influencing Farmers' Adoption of Best Management Practices: A Review and Synthesis. Sustainability 2018, 10, 432. [CrossRef] [PubMed]

36. Pulwarty, R.S.; Sivakumar, M. Information systems in a changing climate: Early warnings and drought risk management. Weather Clim. Extrem. 2014, 3, 14-21. [CrossRef]

37. Sivakumar, M.V.; Mothal, R.P.; Wilhite, D.A.; Qu, J.J. Towards a compendium on national drought policy. In Proceedings of the Expert Meeting on the Preparation of a Compendium of National Drought Policy, Washington, DC, USA, 14-15 July 2011; WMO: Geneva, Switzerland, 2011; p. 135.

38. Salmoral, G.; Rey, D.; Rudd, A.C.; Margon, P.; Holman, I. A Probabilistic Risk Assessment of the National Economic Impacts of Regulatory Drought Management on Irrigated Agriculture. Earths Future 2019, 7, 178-196. [CrossRef]

39. Hannaford, J.; Collins, K.; Haines, S.; Barker, L.J. Enhancing Drought Monitoring and Early Warning for the United Kingdom through Stakeholder Coinquiries. Weather Clim. Soc. 2019, 11, 49-63. [CrossRef]

40. Prudhomme, C.; Hannaford, J.; Harrigan, S.; Boorman, D.; Knight, J.; Bell, V.A.; Jackson, C.; Svensson, C.; Parry, S.; Bachiller-Jareno, N.; et al. Hydrological Outlook UK: An operational streamflow and groundwater level forecasting system at monthly to seasonal time scales. Hydrol. Sci. J. 2017, 62, 2753-2768. [CrossRef]

41. Haro-Monteagudo, D.; Knox, J.W.; Holman, I. D-Risk: A decision-support webtool for improving drought risk management in irrigated agriculture. Comput. Electron. Agric. 2019, 162, 855-858. [CrossRef]

42. Pulley, S.; Collins, A.L. Field-based determination of controls on runoff and fine sediment generation from lowland grazing livestock fields. J. Environ. Manag. 2019, 249, 109365. [CrossRef]

43. Bilotta, G.S.; Krüger, T.; Brazier, R.E.; Butler, P.; Freer, J.; Hawkins, J.; Haygarth, P.M.; MacLeod, C.J.A.; Quinton, J.N. Assessing catchment-scale erosion and yields of suspended solids from improved temperate grassland. J. Environ. Monit. 2010, 12, 731-739. [CrossRef]

44. Rojas-Downing, M.M.; Nejadhashemi, A.P.; Harrigan, T.; Woznicki, S. Climate change and livestock: Impacts, adaptation, and mitigation. Clim. Risk Manag. 2017, 16, 145-163. [CrossRef]

45. Ingram, J. Agricultural adaptation to climate change: New approaches to knowledge and learning. In Climate Change Impact and Adaptation in Agricultural Systems; Fuhrer, J., Gregory, P.J., Eds.; CAB International: Wallingford, UK, 2014; pp. 253-270. 
46. Below, T.B.; Mutabazi, K.D.; Kirschke, D.; Franke, C.; Sieber, S.; Siebert, R.; Tscherning, K. Can farmers' adaptation to climate change be explained by socio-economic household-level variables? Glob. Environ. Chang. 2012, 22, 223-235. [CrossRef]

47. Pyhälä, A.; Fernández-Llamazares, Á.; Lehvävirta, H.; Byg, A.; Ruiz-Mallén, I.; Salpeteur, M.; Thornton, T.F. Global environmental change: Local perceptions, understandings, and explanations. Ecol. Soc. 2016, $21,25$. [CrossRef] [PubMed]

48. Ahnström, J.; Höckert, J.; Bergeå, H.L.; Francis, C.A.; Skelton, P.; Hallgren, L. Farmers and nature conservation: What is known about attitudes, context factors and actions affecting conservation? Renew. Agric. Food Syst. 2008, 24, 38-47. [CrossRef]

49. Defra. Agriculture in the United Kingdom 2017. Report Produced by Department for Environment, Food and Rural Affairs; Department of Agriculture, Environment and Rural Affairs (Northern Ireland); Welsh Assembly Government, The Department for Rural Affairs and Heritage; The Scottish Government, Rural and Environment Science and Analytical Services. 2018. Available online: https://assets.publishing.service. gov.uk/government/uploads/system/uploads/attachment_data/file/741062/AUK-2017-18sep18.pdf (accessed on 15 June 2020).

50. Winter, M.; Lobley, M. Is There a Future for the Small Family Farm in the UK? Report to The Prince's Countryside Fund; Prince's Countryside Fund: London, UK, 2016.

51. Dumont, B.; Ryschawy, J.; Duru, M.; Benoit, M.; Chatellier, V.; Delaby, L.; Donnars, C.; Dupraz, P.; Lemauviel-Lavenant, S.; Méda, B.; et al. Review: Associations among goods, impacts and ecosystem services provided by livestock farming. Animal 2018, 13, 1773-1784. [CrossRef]

52. Smith, P.; Martino, D.; Cai, Z.; Gwary, D.; Janzen, H.; Kumar, P.; McCarl, B.; Ogle, S.M.; O’Mara, F.; Rice, C. Policy and technological constraints to implementation of greenhouse gas mitigation options in agriculture. Agric. Ecosyst. Environ. 2007, 118, 6-28. [CrossRef]

53. Coe, S.; Downing, E. The Agriculture Bill (2019-2020). Briefing Paper Number CBP 8702; House of Commons Library: London, UK, 2020.

54. Hodge, I. Renewing the Governance of Rural Land after Brexit: An Ecosystems Policy Approach. EuroChoices 2019, 18, 4-10. [CrossRef]

55. Downing, E.; Coe, S. Brexit: Future UK Agricultural Policy; Briefing Paepr 8218; House of Commons Library: London, UK, 2018; Available online: https://www.parliament.uk/documents/commons-library/Brexit-UKagriculture-policy-CBP-8218.pdf (accessed on 1 May 2020).

56. Bateman, I.J.; Balmford, B. Public funding for public goods: A post-Brexit perspective on principles for agricultural policy. Land Use Policy 2018, 79, 293-300. [CrossRef]

57. Waylen, K.; Martín-Ortega, J. Surveying views on Payments for Ecosystem Services: Implications for environmental management and research. Ecosyst. Serv. 2018, 29, 23-30. [CrossRef]

58. Bengtsson, J.; Bullock, J.M.; Egoh, B.; Everson, C.; Everson, T.; O'Connor, T.; O'Farrell, P.J.; Smith, H.G.; Lindborg, R. Grasslands-more important for ecosystem services than you might think. Ecosphere 2019, 10, e02582. [CrossRef]

(C) 2020 by the authors. Licensee MDPI, Basel, Switzerland. This article is an open access article distributed under the terms and conditions of the Creative Commons Attribution (CC BY) license (http://creativecommons.org/licenses/by/4.0/). 